\title{
BRAN THE BROKEN: CLASSICAL PRECEDENTS FOR THE FIGURE OF BRAN STARK IN G R R MARTIN'S A SONG OF ICE AND FIRE NOVELS AND IN THE GAME OF THRONES TELEVISION SERIES*
}

\section{S Sharland (University of Kwa-Zulu Natal)}

This article seeks to explain why many viewers and fans of the Game of thrones series and the novels that inspired them were disappointed and frustrated with the ending of the eighth season. Although it has long been observed that kingship often coincided with magical powers or the abilities of the seer in a wide range of early human societies, we have come to prefer the heroes whom we celebrate and the seers or wise people who advise them to be separate entities. Bran Stark endured physical disability as the result of an attempted assassination as a child; either in spite of this or because of this, he developed soothsaying powers as a 'greenseer' and journeyed beyond the Wall to become the next Three-Eyed Raven. While disability has traditionally been linked to the ambiguous powers of the seer, there is also a strong tradition for this not to be associated with kingship. Then there is the nature of Bran himself. In some ways Bran has remained a child, avoiding normal human relationships and the usual progression of life; at the same time, however, Bran is an old man, with hints of omniscience, longevity and even immortality. He fulfils the Jungian puer-senex archetype. Both Classical and other precedents are used to view Bran as an ambiguous and dualistic figure with whom most fans of Game of thrones can no longer sympathize.

Keywords: Classical Reception Studies; Game of thrones; Classical influences on GRR Martin; Game of thrones \& Classical antiquity; Bran Stark as ambiguous mantic personality; puer-senex archetype; Tiresias \& Bran Stark; influence of Ovid's Metamorphoses on Bran Stark; seer and king figures.

Maester Luwin built a little pottery boy and dressed him in Bran's clothes and flung him off the wall into the yard below, to demonstrate what would happen to Bran if he fell ...

G R R Martin A game of thrones 1996/2011:76.

* SPOILER ALERT: The nature of this article has compelled me to refer to events up to the end of GOT Season 8.

1 All quotations from G R R Martin's novels in this article are taken from the 2011 and 2012 paperback editions of Harper-Voyager, although I also refer to the original date of publication in order to distinguish the individual books from one another. Here and there I have found it necessary to shorten some of these excerpts. 
The fear of flying is great because the fear of falling is greater.

\section{Ann Yeoman Now or neverland 1998:51}

Although George R R Martin's series of fantasy novels entitled A song of ice and fire, and the popular HBO Game of thrones (GOT) television series inspired by and broadly based on Martin's novels are set in an imaginary world that largely mirrors the European Middle Ages, Classical scholars have pointed to the additional influence of the ancient world on the franchise. ${ }^{2}$ To some extent this is predictable: Medieval Europe, arguably part of the inspiration for Westeros, long lived under the shadow of the Roman Empire, just as the subjects of the Seven Kingdoms often refer to the former greatness and the sometime 'fall' of Old Valyria. ${ }^{3}$ Then there is the Wall, which Martin himself has revealed was inspired by a visit to Hadrian's Wall: the author stood on the present-day remains and imagined the mixture of fear and curiosity experienced by a Roman legionary on the last bastion between the 'civilized' world and the unknown. ${ }^{4}$ In the Game of thrones franchise, the Wall is much higher than Hadrian's and covered in ice, and it not only separates the 'civilized' folk of Westeros from the supposedly savage Wildlings to the North, but also the world of the Living from that of the Dead.

Other themes and stories, likewise, encourage the ears of a Classicist to prick up. The story, for example, of the spirited and lovely Lyanna Stark, supposedly abducted and raped by the son of the mad and unpopular soon-to-bedeposed king Aerys Targaryen, whose death provokes Robert's Rebellion, and the expulsion of the Targaryens from the Iron Throne, sounds an awful lot like the Roman historian Livy's version of the rape of Lucretia by Sextus Tarquin, son of Tarquinius Superbus (Tarquin the Proud). The beautiful Lucretia's suicide in order to avoid bringing dishonour on her family is the final straw in the Roman people's

2 See Haimson Lushkov 2017, who extensively explores the Classical resonances in Game of thrones.

3 See the discussion of Haimson Lushkov 2017:2-4.

4 In his 2014 interview with Rolling Stone Magazine, Martin revealed that a visit to Hadrian's Wall was the first thing that inspired him to start imagining the world of Game of thrones: 'The Wall predates anything else. I can trace back the inspiration for that to 1981. I was in England visiting a friend, and as we approached the border of England and Scotland, we stopped to see Hadrian's Wall. I stood up there and tried to imagine what it was like to be a Roman legionary, standing on this wall, looking at these distant hills. It was a very profound feeling. For the Romans at that time, this was the end of civilization; it was the end of the world. We know that there were Scots beyond the hills, but they didn't know that. It could have been any kind of monster. It was the sense of this barrier against dark forces - it planted something in me. But when you write fantasy, everything is bigger and more colorful, so I took the Wall and made it three times as long and 700 feet high, and made it out of ice' (Gilmore 2014). 
dissatisfaction with and anger towards the Etruscan royal family, and Brutus' callto-arms is what leads in this case to the expulsion of the Tarquins and the establishment of the Roman Republic in 509 BCE. ${ }^{5}$ The tale of Lyanna's abduction by Rhaegar Targaryen is later, in the television series at least, shown to be unfounded, ${ }^{6}$ but the similarities between what Robert Baratheon, Lyanna's other suitor, believed to be the truth and ultimately acted on, and Livy's account, are uncanny. Perceived parallels between Lyanna and Lucretia resulted in rebellion, usurpation, death, and the establishment of a new order. ${ }^{7}$

In this article, however, I turn my attention to another issue, that of the character of Brandon Stark, commonly known as Bran, the second son and fourth child of Lord Eddard and Lady Catelyn Stark of Winterfell, the stronghold in the north of the Seven Kingdoms. The pace of the Game of thrones television series has vastly outstripped the writing speed and perhaps also the interest of the author of the novels on which it is based; the plotline of the series has also diverged significantly from the later books, particularly from the sixth season onwards. In what follows, however, I shall be looking at both the presentation of Bran in the books published to date and in the television series up to the conclusion of season eight. Martin is said to have been consulted by the series' creators David Benioff and D B Weiss in constructing the ending of the eighth season. ${ }^{8}$ However, as Martin is still in the process of writing the final books of the $A$ song of ice and

5 See Livy 1.57.6-59.6. Classicists have also noted the connection with Helen of Troy, whose abduction or elopement, depending on whom you believe, famously sparked war and destruction. The online article of Love 2017 focuses on the similarities between Lyanna Stark and Helen of Troy. Haimson Lushkov 2017:183-189 looks at the parallels of Lyanna Stark's story with both Helen of Troy and Lucretia.

6 In the seventh season of the television series Game of thrones, Bran, who has by now fully developed his soothsaying powers, discovers and reveals that Rhaegar and Lyanna had actually been in love with each other and had eloped together. With the archival help of Jon's friend Samwell Tarly, it is also discovered that Rhaegar and Lyanna were formally wed after the annulment of Rhaegar's marriage to Elia Martell. It is also finally revealed that Jon Snow is really not Eddard Stark's bastard but the legitimate son of his sister Lyanna and Rhaegar, and that his real name is Aegon Targaryen (GOT S07E07). When Lyanna died in Dorne, she entrusted the infant to her brother Eddard Stark who was sworn to secrecy. Eddard Stark even kept the truth of Jon Snow's identity from his own wife, Catelyn, who, to her dying day resented the fact that her husband supposedly had an illegitimate son.

7 It is striking that the names of the women both begin with 'L-' and end in '-a' (and the second letter of Lyanna's name ' $y$ ' is often a rendition of the Greek letter upsilon, which can also be rendered ' $u$ ' in English) and the names of the dynasties that their stories unsettle both begin with the letters 'Tar-' and end in '-n', Tarquin and Targaryen (at least in the Anglicized version of the former).

8 See the online article of Miller 2019. 
fire novel series, there are possibilities that his own final version may diverge significantly from that of the television series. My motives for writing the present paper are an attempt to explain why many viewers and fans of Game of thrones were disappointed and frustrated by the ending of the eighth season. At the same time, however, I intend to show that the crowning of Bran Stark at the end of the television series is the fulfillment of a narrative arc that has been in the backdrop since the beginning of the novels.

One of the big surprises of the eighth and apparently final season of the Games of thrones television series was that neither Jon Snow nor Daenerys Targaryen emerged as victors in the end. Another surprise of the final episode was that after the destruction of King's Landing by Daenerys and Drogon (a shock for many viewers and likewise for the actress herself), she was assassinated by her disillusioned lover (and nephew) Jon Snow (GOT S08E06). Thus we see a repetition of the tale of the mad Targaryen monarch being justifiably dispatched by tyrannicide at the hands of one who had sworn his undying loyalty. Likewise, at the end of Robert's Rebellion, Mad King Aerys Targaryen was killed by the 'Kingslayer' Jaime Lannister, despite the fact that as a member of the 'Kingsguard', he had sworn to protect the ruler (in this case Jon is a 'Queenslayer' and also a Targaryen himself, although he has only recently come to learn of this). However, just as Jaime was unseated by Eddard Stark, and the throne awarded to Robert Baratheon, ${ }^{9}$ Jon does not get to sit on the Iron Throne either (which thanks to Daenerys' angry dragon Drogon, no longer exists), but a tribunal of representatives of all the lords and ladies from the Seven Kingdoms decides to punish Jon by sending him back to become one of the Night's Watch on the Wall. Instead, at the suggestion of Tyrion, Bran Stark, whom Tyrion refers to as 'Bran the Broken', is at last chosen as king (GOT S08E06).

Fans did not welcome this choice, especially as Bran reveals that he has specifically come south in order to take up this position as king, thus suggesting that he is omniscient. ${ }^{10} \mathrm{He}$ also approves and carries out the sentence of Jon Snow to serve on the Wall, which will ensure that Jon never marries nor has legitimate offspring. Neither will Bran have any offspring, it is revealed, being prevented by his disability. This proves to be a strategy that will significantly reduce the chances of another dynastic power struggle developing. My aim here is to explain why many viewers and fans have struggled to accept the choice of Bran as the king, despite our earlier sympathy for the character who has struggled with his

9 This event is recounted from memory by Eddard Stark to his friend King Robert in the first novel A game of thrones (1996/2011:111).

10 When, for example, Tyrion asks Bran if he is prepared to be king, the latter replies: 'Why do you think I came all this way?' (GOT S08E06). Bran's question likely refers to his extended journeying as a whole, and not just to his coming south to King's Landing. 
disabilities and emerged victorious. I propose to use both Classical and other precedents to view Bran as an ambiguous and dualistic figure with whom most fans of Game of thrones can no longer sympathize.

Although it has long been observed that kingship often coincided with magical powers or the abilities of the seer in a wide range of early human societies, ${ }^{11}$ for some reason we have come to prefer the heroes whom we celebrate and the seers or wise people who advise them to be separate entities. ${ }^{12}$ Bran Stark endured physical disability as the result of an attempted assassination as a child; either in spite of this or because of this, he developed the soothsaying powers of a 'greenseer' and journeyed beyond the Wall to become the next Three-Eyed Raven (called the 'three-eyed crow' in the novels). ${ }^{13}$ While disability has traditionally been linked to the ambiguous powers of the seer, there is also a strong tradition for this not to be associated with kingship. Rather, inspired perhaps by the example of Aeneas in Virgil's Aeneid, we have become accustomed to the idea that the king should be the epic hero warrior type, the fighter and the brave, dutiful, sometimes troubled leader, who relies on another for spiritual guidance and mentorship while he does his best in the day-to-day political sphere. In Game of thrones the obvious person who fits this category by descent (from both the Starks and the Targaryens), and because of his character and actions is Jon Snow, originally introduced as Bran's illegitimate half-brother, but ultimately revealed as his cousin. Jon and Bran, in fact, mirror each other in numerous ways. ${ }^{14}$

11 See Frazer 1922:166: 'At a certain stage of early society the king or priest is often thought to be endowed with supernatural powers or to be an incarnation of a deity'.

12 Frazer 1922:173-175 also observed that many societies eventually found it more useful to separate temporal from spiritual powers; in some societies the original association of kingship and magic was long preserved in the appearance of two kings reigning side by side, one endowed with spiritual powers and the other with civil authority (1922:174). Where kings or leaders are disabled, I would argue, like Oedipus in Sophocles' Oedipus Rex, they are often ultimately revealed as unsuitable for the role.

13 I will compromise by referring wherever possible to the arch-seer as the Three-Eyed Crow/Raven. A literal crow with an extra eye in the middle of its forehead appears in Bran's dreams while he is in a coma. The figure is symbolic of Bran himself, his journey and what he will become; interestingly, 'Bran' means 'crow' or 'raven' in the Welsh language.

14 Like Bran, Jon also dies and is resurrected, at least in the television series. Jon is stabbed to death during a mutiny at the Night's Watch at the end of Season 5 (GOT S05E10), but he is subsequently brought back to life by Melisandre at the beginning of the next season (GOT S06E01). 
In some ways it is not surprising that 'Bran the Broken' is chosen as king at the end of the eighth season of the television series Game of thrones. As one of the children of the Stark family, on whom the novels focus from the beginning, Bran is an important character particularly in the earlier books of $A$ song of ice and fire. In fact, Bran is the first 'focalizer' ${ }^{15}$ or point-of-view character Martin uses immediately after the Prologue in his initial novel $A$ game of thrones. ${ }^{16}$ In an interview with Rolling Stone Magazine in 2014, Martin observed that this point-of-view narrative from Bran's perspective gives the reader the impression that Bran is going to be the hero of the story. We get the feeling that here is the main character whom we shall follow throughout, only for us to be shocked and horrified when Bran is thrown from the tower of the First Keep by Jaime Lannister early in the first novel. ${ }^{17}$ This episode in the novel is made more shocking by being narrated from Bran's point of view (1996/2011:72-81), although other 'focalizers' have been introduced by this time. ${ }^{18}$ In the same interview with Rolling Stone,

15 I use this narratological term, which stems ultimately from the work of Genette, in spite of problems with its definition. Martin's narrative style is particularly interesting due to his consecutive use of multiple external 'focalizers', many of which he 'kills' even while they are the focalizer. This lends an element of surprise to his writing.

16 The first chapter after the Prologue in A game of thrones (1996/2011:11-18) is narrated entirely from the perspective of Bran who, at age seven, is for the first time allowed to accompany his father and brothers on an expedition to execute a deserter from the Night's Watch (the focalizer of the Prologue). Bran is warned by his fourteen-year-old half-brother Jon Snow not to look away when their father Eddard Stark beheads the man, and is subsequently complimented by Jon when he behaves bravely (1996/2011:12-13). Shortly thereafter they find the dead female direwolf and are permitted by their father to adopt her pups (1996/2011:15-18). In the following chapter, narrated from the perspective of Catelyn Stark, Eddard tells his wife that she would have been proud of Bran's behaviour at the execution. 'I'm always proud of Bran,' is her reply (1996/2011:21).

17 Martin observed: 'Bran is the first viewpoint character. In the back of their heads, people are thinking that Bran is the hero of the story. He's young King Arthur. We're going to follow this young boy - and then, boom: You don't expect something like that to happen to him ...' (Gilmore 2014). This is the first time in the book or the series where we experience Martin's tendency to 'kill off' his 'focalizers' or viewpoint characters - characters whom we've been schooled by other novels and series to believe are indestructible. This is used to good effect also in the death of Eddard Stark and in other cases. I note, however, that the later seasons of the television series have kept alive certain characters whom Martin has 'killed off' in his novels.

18 This chapter is only the second time Bran is used as the focalizer. Bran is described as being bored when the older males all go off on a hunt with King Robert, whose party is visiting his family seat of Winterfell, so he decides to go climbing the walls of the castle, a frequent pastime of his since he was very young (1996/2011:72-77). Bran is very good at climbing, although we are told that his mother has had fears for his safety, and has tried to stop this activity (1996/2011:75). However, the agile Bran 
Martin revealed that Bran's 'fall' was one of the things that 'hooked' his readers early in the first book. ${ }^{19}$ This incident also appropriately provided a 'cliffhanger' towards the end of the first episode of the television series (GOT S01E01).

\section{'Fall' from the tower: Bran's first 'death' and 'rebirth'}

Themes of life, death, and rebirth are strongly associated with Bran. As a character he is associated with death and near-death experiences, and for long stretches of the novels, Bran is assumed to be dead or dying, but ultimately he recovers and 'resurrects' more than once in the story. When Bran is pushed from the tower by Jaime Lannister, in both the first novel and in the television version, we, as readers and viewers, anticipate his death. For us, at that point, Bran may as well be dead. It is only in subsequent chapters and episodes that we discover that Bran is in a coma. ${ }^{20}$ Still, his life hangs in the balance, and Bran's loved ones and close family wonder if he will make it. We hear about what the injured and comatose Bran looks like from Jon Snow's perspective when he braves a confrontation with his stepmother Catelyn Stark to bid farewell to his half-brother before he departs for the Night's Watch:

She was holding one of his hands. It looked like a claw. This was not the Bran he remembered. The flesh had all gone from him. His skin stretched tight over bones like sticks. Under the blanket, his legs bent in ways that made Jon sick. His eyes were sunken deep into black pits; open, but they saw nothing. The fall had shrunken him somehow. He looked half a leaf, as if the first strong wind would carry him off to his grave. ${ }^{21}$

G R R Martin A game of thrones (1996/2011:89).

reasons that he is an experienced climber and never falls. On this occasion, however, Bran's unusual mobility means that he accidentally comes across the twins Jaime and Cersei Lannister engaging in secret adulterous incest; it is Cersei who insists that Jaime take action as the child has seen them (1996/2011:80-81).

19 See Gilmore 2014, where Martin is quoted as saying: 'I've had a million people tell me that was the moment that hooked them, where they said, "Well, this is just not the same story I read a million times before"'.

20 Naturally, Jaime and Cersei Lannister are hoping that Bran will die before regaining consciousness, as their perceptive brother Tyrion, who is well aware of the nature of the twins' relationship, shrewdly grasps when breakfasting with them after the event: 'The glance that passed between Jaime and Cersei lasted no more than a second but [Tyrion] did not miss it' (Martin 1996/2011:86).

21 The image of humans as a 'generation of leaves' goes back to Homer Iliad 6.146-149; 21.464-466, and is alluded to by a number of Classical authors such as Mimnermus, Simonides, Aristophanes, Virgil, and Horace (see Sider 1996), and later authors. Although Martin is well-educated and well-read, it is difficult to determine to what 
The description of Bran's skeleton-like physique and his eyes being sunken but open in his comatose state makes it seem as though he is truly already a corpse. Likewise, when a mystery assassin attacks Bran while in the care of his mother Catelyn Stark some time later, as everyone else has run off to quench a fire that was set as a distraction, the would-be assassin excuses himself to Catelyn by saying what many must have thought: 'It's a mercy ... He's dead already' (Martin 1996/2011:126). Catelyn thinks otherwise and, at great physical cost to herself, holds the assassin off for long enough until Bran's direwolf, which is at that stage still unnamed, runs into the room, jumps at the man, and kills him (Martin 1996/2011:126-127). The scene establishes the close psychic bond that Bran has with his direwolf, just as the other Stark children are closely linked to their wolves. ${ }^{22}$

While in the coma, Bran dreams that he is continuously falling. In this dream, he is approached by a three-eyed crow which claims to be trying to teach him to 'fly'. The third time that Bran is used as 'focalizer' in the first novel, we join him in his dreams, which seem to represent the struggle between Bran's choice of giving in to death (falling) or opting for life (flying). ${ }^{23}$ The epiphany described in this chapter, which Bran experiences just before waking from his coma, is the first time he shows any signs of developing 'second sight' or 'greenseeing', as it is called in the Game of thrones universe. Instructed on how to 'fly' by the three-eyed crow, Bran has a transcendental experience of being able to view the whole of the Seven Kingdoms from the air, but his vision of 'the heart of winter' as he gazes far into the North is also prophetic, and ultimately anticipates his pivotal role in combating the Night King and the army of White Walkers in the eighth season of the television series:

He looked deep into the heart of winter, and then he cried out, afraid, and the heat of his tears burned on his cheeks.

Now you know, the crow whispered as it sat on his shoulder. Now you know why you must live.

extent he is aware of the specific provenance of all his references. Martin may just be a particularly sensitive siphon for cultural references. This concern also relates to the parallels with passages from Callimachus and Ovid which I shall raise below in relation to Bran's 'error' of 'seeing' something he should not.

22 The fact that the sigil of House Stark is the wolf or 'direwolf', a species of larger-thannormal wolf invented by Martin for his fantasy world, links the family with ancient Rome; the wolf was a symbol of Rome due to the founding myth of the twins Romulus and Remus having been suckled by a she-wolf.

23 See Martin 1996/2011:154-158. 
'Why?' Bran said, not understanding, falling, falling.

Because winter is coming.

Bran looked at the crow on his shoulder, and the crow looked back. It had three eyes, and the third eye was full of a terrible knowledge. Bran looked down. There was nothing below him now but snow and cold and death, a frozen wasteland where jagged blue-white spires of ice waited to embrace him. They flew up at him like spears. He saw the bones of a thousand other dreamers impaled upon their points. He was desperately afraid ...

... Now, Bran, the crow urged. Choose. Fly or die.

Death reached for him, screaming.

Bran spread his arms and flew.

G R R Martin A game of thrones (1996/2011:157).

As Bran gradually regains consciousness, his direwolf jumps onto his bed, and he feels the animal's warmth in contrast to all the freezing imagery of death and winter he has been dreaming. When Bran awakens from his coma, the first thing he says is that his direwolf's name is 'Summer'. ${ }^{24}$

The image of the bird - in this case a crow, but in the series a raven with a third eye in the middle of its forehead is symbolic here, as in many human cultures, of psychic knowledge or enlightenment. The crow in this scene pecks Bran in the middle of his forehead, as a symbolic awakening of his psychic abilities. ${ }^{25}$ Although imagery of eyes and seeing being linked to knowledge and psychic abilities is universal by now, the locus classicus for this is Sophocles' Oedipus rex. There we meet the blind seer Tiresias, who, according to one version of the story, was deliberately caused to become disabled, like Bran, for seeing something that he should not. In Callimachus' Bath of Pallas (Hymn 5), Tiresias is struck blind by the goddess Athena for accidentally stumbling upon her while she is bathing. ${ }^{26}$ Subsequently, mainly due to the intercessions of his mother Chariclo, a favourite of Athena who was bathing along with her, the goddess compensates Tiresias with the ability to prophesy, with powers of augury ('knowledge of birds'), as well as extreme longevity and the advantage of retaining the memory of

24 Martin 1996/2011:158.

25 Martin 1996/2011:158. Birds are, of course, the focus of augury in the Classical world, as we shall see in relation to Tiresias below. In the GOT universe, ravens are also used to deliver messages between different locations.

26 See Callimachus Hymn 5.75-78. Callimachus makes plain that Tiresias unintentionally

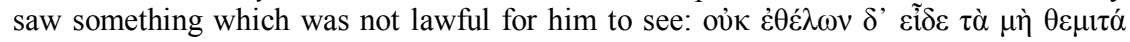
(Hymn 5.78). 
his former life in the Underworld (Callimachus Hymn 5.121-130). Bran is also punished and almost killed, ${ }^{27}$ like many Classical figures, for seeing something that he was not supposed to - Jaime and Cersei Lannister, the latter the wife of King Robert, engaging in incest:

... Her hands buried themselves in his hair, his tangled golden hair, and pulled his face down to her breast.

Bran saw her face. Her eyes were closed and her mouth was open, moaning. Her golden hair swung from side to side as her head moved back and forth, but still he recognized the queen.

He must have made a noise. Suddenly her eyes opened, and she was staring right at him. She screamed ...

... Faces appeared in the window above him.

The queen. And now Bran recognized the man beside her. They looked as much alike as reflections in a mirror.

"He saw us," the woman said shrilly.

"So he did," the man said ... He stood Bran up on the sill. "How old are you, boy?"

"Seven," Bran said, shaking with relief ...

The man looked over at the woman. "The things I do for love," he said with loathing. He gave Bran a shove.

Screaming, Bran went backward out the window into empty air. There was nothing to grab on to. The courtyard rushed up to meet him ...

G R R Martin A game of thrones (1996/2011:80-81).

In the above scene, where Bran accidentally comes across them in their tryst, the identical aspect of the twins is emphasized when Jaime and Cersei are said to look 'as much alike as reflections in a mirror' (Martin 1996/2011:80). The Lannister twins are also both described as 'golden', which, apart from being one of the heraldic hues of their family, literally describes their colouring. The repeated emphasis on 'golden' gives the impression that Bran has accidentally intruded upon incestuous brother and sister gods ('his tangled golden hair...', '... her

27 The case of Actaeon, who is transformed into a stag and killed by his own hounds for stumbling across the goddess Artemis bathing, is contrasted with the more fortunate fate of Tiresias, who was merely blinded, and will be handsomely compensated by Athena, at Callimachus Hymn 5.107-118. Ovid also treats the case of Actaeon at Met. 3.131-252. 
golden hair ...', Martin 1996/2011:80). ${ }^{28}$ Likewise, in the temporarily amnesiac Bran's gradually returning memories of the event, it is the 'golden' aspect of Jaime Lannister that is continually emphasized. ${ }^{29}$ The emphasis on Bran's error of 'seeing' is also stressed in the original scene by Cersei's shrill assertion that 'He saw us' (1996/2011:81), just as Classical goddesses become outraged at having been seen by mortals and therefore demand that the mortal be punished.

In another version of the Tiresias myth, recounted at Ovid Metamorphoses 3.324-331, the future seer changes gender when he comes across two snakes mating and strikes them; after living as a woman for seven years, in the eighth Tiresias comes across the same snakes mating, strikes them again, and turns back into a man. Having experience as both sexes, Tiresias is consequently chosen as a judge $^{30}$ in a dispute between husband and wife (also brother and sister) Jupiter and Juno, king and queen of the Olympian gods, as to which gender - male or female - enjoys sex more. Tiresias sides with Jupiter and replies that women enjoy sex more than men. This angers Juno so much that she strikes Tiresias blind, and while even Jupiter cannot restore his physical sight, he tempers Juno's curse with second sight, the ability to see the future (Ovid Metamorphoses 3.332-338).

There are a number of commonalities with the scene that leads to Bran's tragic punishment by Jaime and Cersei, including: intrusion on a mating pair (while the Lannisters are not snakes, they are certainly untrustworthy and coldblooded in their cruelty), involvement in the battles of a powerful, incestuous brother-and-sister duo to the detriment of the innocent outsider, the vengeful spitefulness of the sister in particular, who calls for the punishment, the disabling

28 Golden hair is a common feature of gods, goddesses, heroes and heroines from Homer onwards. Cersei's haughty glamour brings her close to goddess status, and it may not be coincidental that her name is pronounced in the same way as the English rendition of Circe, who is both a goddess and enchantress ('witch') in the Odyssey. As her uncle Kevan Lannister reflects (somewhat misguidedly) after Cersei's naked 'Walk of shame' through the streets of King's Landing in the second volume of $A$ dance with dragons: 'No queen could expect to rule again after that. In gold and silk and emeralds Cersei had been a queen, the next thing to a goddess ...' (Martin 2011/2012 (b):482).

See Martin 1996/2011:155, where Jaime appears as 'a shining golden face'. In the second novel A clash of kings (Martin 1998/2011:237), Bran dreams that he is hanging from a tower: " Help me!" he cried. A golden man appeared in the sky above him and pulled him up. "The things I do for love," he murmured softly, as he tossed him out kicking into empty air'. Eventually Bran realizes the identity of this figure: 'The falling, Bran thought, and the golden man, the queen's brother, he scares me too, but mostly the falling ...' (Martin 1998/2011:397).

30 The mock-legal language of this 'judgement' has been investigated by Coleman 1990 and Balsley 2010; for a feminist reading of the incident, see Liveley 2003. 
of the victim, and finally, 'second sight' being granted to him in compensation. ${ }^{31}$ Another curious link between Bran and Tiresias is the prominence, in both tales, of the number seven, a numeral often attributed with magical qualities. Tiresias spends seven years as a woman, in Ovid's account, while other ancient versions of his story have him undergoing as many as seven sex changes. ${ }^{32}$ As revealed in the passage cited above, Bran is seven years of age when thrown out of the tower by Jaime Lannister, which may have symbolic significance, or which may simply be because a child of that age has sufficient comprehension to recall and relate what he has seen. While we expect sympathy from Lannister toward a child of such tender years, the fact that the boy knows and can say how old he is, indicates that he is not a simpleton. He will remember what he has seen.

Imagery of death versus life, ${ }^{33}$ disability versus ability, ignorance versus knowledge, 'falling' versus 'flying' continue to associate themselves with Bran as the novels progress:

Bran did not remember falling, yet they said he had, so he supposed it must be true. He had almost died. When he saw the weatherworn gargoyles atop the First Keep where it had happened, he got a queer tight feeling in his belly. And now he could not climb, nor walk nor run nor swordfight, and the dreams he'd dreamt of knighthood had soured in his head.

G R R Martin A clash of kings (1998/2011:65).

His original ambitions of becoming a knight having been thwarted by his disabilities, the crippled Bran lies in bed and is dependent on others to perform the simplest of daily tasks. Unable to walk by himself, Bran is carried around on the back of the giant stable-attendant and simpleton Hodor, much like an infant or

31 It is never made explicit whether Bran gains his 'greenseeing' ability as a form of compensation for his suffering and near-death experience (as we shall see, Jojen Reed acquires the gift after almost dying as a young child), or whether Bran was always destined for this. It is clear, however, in the scene where the Crow teaches Bran to 'fly', that he must either 'fly' or 'die'; so his soothsaying abilities enable him to save his own life, and later those of others.

32 See discussion of Carp 1983:275-276.

33 When Jon Snow receives word on the Wall that Bran has awoken from his coma, he rejoices inordinately in the news that his brother is going to live, despite the fact that Bran will be permanently crippled. We see both Jon's close relationship with Bran and his ecstatic joy in his brother's recovery as Jon runs everywhere telling the men of the Night's Watch: 'My brother is going to live!'. Jon also runs into the common hall, and finds Tyrion Lannister, a visitor at the Wall, who is just finishing his meal; Jon hoists the dwarf into the air in joy and whoops that 'Bran is going to live!' Tyrion looks startled, of course realizing what this will mean for his brother and sister (Martin 1996/2011:182). 
young child. At the same time, as his family members gradually leave Winterfell for other destinations and pressing missions, Bran remains behind as the most senior Stark in the castle, and, although assisted by caregivers and underlings, he is compelled to take on responsibilities beyond his years. In one scene Bran reflects self-pityingly on his desertion by his family members, naturally unaware of how they all rallied around when he was unconscious: 'Yet to Bran it felt as if they had all died while he had slept ... or perhaps Bran had died and they had forgotten him' (Martin 1996/2011:232).

There are several characters who guide Bran to accept his physical disabilities and to bring out his new-found psychic gifts and whose support and information ultimately lead to his destiny of journeying beyond the Wall to become the Three-Eyed Crow/Raven. The first of these is Old Nan, the ancient retainer whose stories about the White Walkers and the Children of the Forest are dismissed as fairy tales by most people, but which grab Bran's imagination, and to which he frequently refers. ${ }^{34}$ Old Nan's great-grandson Hodor is another support for Bran, as he gradually comes to be Bran's legs and eventually carries Bran all the way beyond the Wall to the cave of the Three-Eyed Crow/Raven; ultimately, Hodor will give his life to 'hold the door' and save Bran and his party when the cave of the Three-Eyed Crow/Raven is attacked by the Night King. Bran's direwolf Summer is also highly significant in that Bran learns to "warg' ${ }^{35}$ into the wolf and inhabit the direwolf's skin. He is able to experience much in this capacity, although Bran initially thinks that he is only dreaming about being a wolf when these 'greendreams' begin.

Just as important, however, are the brother-and-sister duo Meera and Jojen Reed, who are Crannogmen, swamp-dwelling poor folk who apparently catch frogs and other small creatures to eat. They are the children of Howland Reed, a staunch and loyal supporter who once saved the life of Bran's father Eddard Stark. ${ }^{36}$ Jojen Reed is himself a 'warg' or 'greenseer'. Like Bran, who developed this ability after almost dying in his 'fall' from the tower, Jojen reveals that a neardeath experience also precipitated the development of his own psychic abilities: " "When I was little I almost died of greywater fever. That was when the crow came to me"" (Martin 1998/2011:396). Jojen reveals that Bran is the 'winged wolf' and that the Crow/Raven has sent the Reeds to break Bran's chains (Martin

34 See e.g. Martin 1996/2011:230-234.

35 'Warging', another term seemingly invented by Martin, is 'a rare ability that lets a person transport their spirit into the body of another living being — usually an animal allowing them to travel around and see through its eyes ...' (a good explanation given by Finnis 2019). Bran normally 'wargs' into his direwolf Summer, but he later learns to 'warg' into Hodor when necessary (see Martin 2011/2012:69-70).

36 See Martin 1998/2011:299, 301. 
1998/2011:396). While Bran's disability has been caused by the Lannister twins, a sister-and-brother duo that is incestuous, destructive and negative, at least as far as Bran is concerned, he is redeemed by contrast by a supportive, nurturing, positive sister-and-brother team in the guise of the Reeds.

\section{In the crypts of Winterfell: Bran's second 'death' and 'rebirth'}

Another source of support Bran receives comes from Osha, the Wildling woman who is captured when her party attacks Bran's excursion when he goes out riding for the first time after his accident, using a saddle fitted for him by Tyrion Lannister. ${ }^{37}$ Osha eventually turns out to be an ally for Bran, and her stories of life beyond the Wall inspire him, as well as her encouragement of his belief in the Old Gods. She is also one of those who saves Bran's life, together with that of his brother Rickon, when Theon Greyjoy invades Winterfell. In the novel, Osha pretends to 'bend the knee' and join Theon's side, although from Bran's perspective it looks like she is really betraying him. ${ }^{38}$ Shortly thereafter, we see, from Theon's perspective as focalizer, what happens when he wakes up to find that Bran and Rickon are missing from their beds. ${ }^{39}$ In the series, Osha feigns receptiveness to Theon's sexual advances, but tricks him by escaping with the princes while he is asleep (GOT S02E06). Theon subsequently kills two peasant children instead of the princes and hangs up their remains so that everyone would believe that Bran and Rickon were murdered on his orders. ${ }^{40}$ This is the second time that Bran 'dies' in the novels, although in this case he is only widely thought to be dead. Even Bran's mother Catelyn goes to her grave believing that her youngest sons are dead. ${ }^{41}$ Ironically, the Stark children and their attendants hide in

37 Martin 1996/2011:383-395.

38 Martin 1998/2011:608.

39 Martin 1998/2011:650-664. In the novel it is implied (1998/2011:664) that Theon may know where Bran and Rickon are hiding, but he still chooses not to pursue them, and kills and disfigures the miller's children instead, who are of a similar age to Bran and Rickon (1998/2011:732).

40 It is some time before this ruse is revealed: 'On their iron spikes atop the gatehouse, the heads waited. Theon gazed at them silently while the wind tugged on his cloak with small ghostly hands. The miller's boys had been of an age with Bran and Rickon, alike in size and coloring, and once Reek had flayed the skins from their faces and dipped their heads in tar, it was easy to see familiar features in those misshapen lumps of rotting flesh' (Martin 1998/2011:732). The children's burnt full bodies are on show in the series, whereas only their heads are tarred and put on display in the novel.

41 See e.g. Martin 2000/2011:35, where Catelyn, who is visiting her dying father Lord Hoster Tully at Riverrun, reflects on 'the sons she had lost, her sweet Bran and her little Rickon, slain at the hand of Theon Greyjoy'; cf. 2000/2011:39, where Catelyn mentions the 'loss' of her younger sons in a letter to her sister. 
the crypts below Winterfell, where the ancient Kings in the North and the ancestors of the Starks are buried. It is only when Bran eventually again appears as focalizer at the end of $A$ clash of kings that his survival is confirmed. ${ }^{42}$

The underground crypts of Winterfell are both a literal tomb but also a symbolic womb, out of which the supposedly 'dead' Bran is reborn, a 'cocoon' from which he emerges able to 'fly'. Bran, his brother Rickon, and his companions Meera and Jojen, assisted by Osha and Hodor, spend innumerable days and nights hiding in the utter darkness of the Winterfell crypts. While 'incubating' in a sense with the five others in the crypts, Bran finally develops his 'second sight' and is able to 'warg' into his direwolf at will:

He remembered who he was all too well; Bran the boy, Bran the Broken. Better Bran the beastling. Was it any wonder he would sooner dream his Summer dreams, his wolf dreams? Here in the chill damp darkness of the tomb his third eye had finally opened.

G R R Martin A clash of kings (1998/2011:864).

When Bran discovers by 'warging' into his direwolf Summer that Winterfell has been burnt and abandoned, they decide that it is now safe for them to emerge from the shadows. At the end of the second novel, the decision is made to separate Bran and Rickon for purposes of safety; Osha departs with Rickon, while, carried in a basket on Hodor's back, Bran heads north under the guidance of Meera and Jojen Reed. His mission is to journey beyond the Wall and to find the cave of the ThreeEyed Crow/Raven. Although Bran's physical disabilities mean that he has failed to become the knight he dreamt of being as a young boy, his long journey to the north and his quest to find the Three-Eyed Crow/Raven mean that he will be no less an epic hero. ${ }^{43}$ Images of death, rebirth and regeneration coalesce in the final words of the second novel of $A$ song of ice and fire, as Bran reflects both on his home and himself:

The stone is strong, Bran told himself, the roots of the trees go deep, and under the ground the Kings of Winter sit their thrones. So long

42 Martin 1998/2011:862-873.

43 The genre of epic traditionally features not only great wars and fighting, on the model of the Iliad, but also great journeys and adventures, on the model of the Odyssey. It is interesting that the Welsh and Irish epics which feature characters called Bran or Brandon are all about great journeys, sometimes journeys to the Celtic 'Otherworld' or spiritual plane. Bran Stark's journey is not only physical, in that he must get to the cave of the Crow/Raven, but also spiritual. Like Odysseus, too, Bran also has to visit a type of Underworld, as we shall see. 
as those remained, Winterfell remained. It was not dead, just broken. Like me, he thought, I'm not dead either.

G R R Martin A clash of kings (1998/2011:873). ${ }^{44}$

As Martin's series of novels progresses, Bran appears less often as the point-ofview character or focalizer. On their journey north, Bran and his group stop for a time in an old, abandoned watchtower Bran has dubbed 'Tumbledown Tower'. ${ }^{45}$ In the novels at this point, Bran is nine years old to Jojen's thirteen, something which, given all that he has been through, is easy to forget. Bran's boredom with his current circumstances and his excitement at being able to run around as a wolf encourage him to spend most of his time 'warging' into the skin of his direwolf, Summer. Jojen, however, cautions him not to do this too much, and keeps on reminding him of his human identity. Bran thinks petulantly: 'At Winterfell he wanted me to dream my wolf dreams, and now that I know how he's always calling me back' ${ }^{96}$ Jojen points out that Bran is in danger of permanently becoming his direwolf if he "wargs' into Summer too much. ${ }^{47}$ Bran has to face the choice of whether to stay 'dead' (as far as other people are concerned, since everyone thinks that he has died) and ironically safe at 'Tumbledown Tower', or whether to venture further northwards in search of a better teacher than Jojen, but at the same time risk detection and possible death. Eventually, however, the young Bran bravely asks his friends to take him north to 'the Crow'. ${ }^{48}$

\section{Katabasis to the cave of the Three-Eyed Crow/Raven}

Bran's journey to the cave of the Three-Eyed Crow/Raven in the north is in some manner a katabasis, a Classical journey to the Underworld or the World of the Dead. ${ }^{49}$ As Bran's party proceeds northwards, beyond the Wall, for some time they are joined by a mysterious ranger who has a pale face but black, cold hands, whom

44 There are striking echoes of J R R Tolkien, arguably one of Martin's strongest influences, in these final words of the second novel. The verses recited in Tolkien's The fellowship of the ring seem particularly apt both to this occasion and to Bran's story in general: "All that is gold does not glitter, / Not all those who wander are lost; / The old that is strong does not wither, / Deep roots are not reached by the frost. / From the ashes a fire shall be woken, / A light from the shadows shall spring. / Renewed shall be blade that was broken; / The crownless again shall be king' (Tolkien 1954/1993:265).

45 Martin 2000/2011:125.

46 Martin 2000/2011:127.

47 Martin 2000/2011:131.

48 Martin 2000/2011:132.

49 Caves, like crypts, are liminal spaces for many cultures, numinous locations perceived as halfway between the worlds of the living and the dead, the material and the spiritual. See the Sibyl's cave at Virgil Aeneid 6.42-44. 
they call 'Coldhands'; there is a strong suspicion that Coldhands, who never eats and cannot pass south of the Wall, ${ }^{50}$ nor enter the cave of the Crow ${ }^{51}$ is actually a dead man, ${ }^{52}$ perhaps Bran's dead uncle Benjen Stark, but as he consistently leads them out of danger, they acquiesce in the presence of this rather sinister psychopomp. Likewise, as the group proceeds northwards, Jojen Reed grows weaker and his sister Meera becomes ever more protective of him. Death stalks them in more ways than one, as Jojen and his sister both know that, at the end of the journey, he will die.

Helped by Coldhands to fight off an attack by wights, Bran and his party are met by a Child of the Forest, Leaf, who conducts them to the cave of the ThreeEyed Crow/Raven or greenseer. The katabasis impression is strengthened by the fact that the final leg of their journey to the cave of the Three-Eyed Crow/Raven is a steep descent, and they also hear the sound of an underground river. ${ }^{53}$ This is reminiscent of the underground rivers which were said to flow in the Classical Underworld. ${ }^{54}$ The Three-Eyed Crow is enthroned in his underground cave like Hades, the god of the Classical Underworld, corpse-like, immobile, and inextricably intertwined with the tree in and under which he sits:

His body was so skeletal and his clothes so rotted that at first Bran took him for another corpse, a dead man propped up so long that the roots had grown over him, under him, and through him. What skin the corpse showed was white, except for a bloody blotch that crept up his neck to his cheek. His white hair was fine and thin as root hair and long enough to brush against the earthen floor. Roots coiled around his legs like serpents ...

G R R Martin A dance with dragons (2011/2012:206)..$^{55}$

What completes this ambiguous picture of excessive, inextricable human and vegetable growth, repulsive senectitude, decay and death, is the fact that the ThreeEyed Crow/Raven ironically has only one red eye, which stares at Bran 'shining

50 Martin 2011/2012:79.

51 Martin 2011/2012:197.

52 This adds a good deal of suspense to the tale: 'The ranger wore the black of the Night's Watch, but what if he was not a man at all? What if he was some monster, taking them to the other monsters to be devoured?' (Martin 2011/2012:72).

53 Martin 2011/2012:205.

54 For the rivers of the Classical Underworld, see Homer Odyssey 10.513-515 (Acheron, Phlegethon and Cocytus); $c f$. Virgil Aeneid 6.295-330 (Acheron, Cocytus, and Styx), 550-551 (Phlegethon), 703-751 (Lethe).

55 The image of the skeletal Crow/Raven parallels the image of Bran as a skeletal invalid as seen through the eyes of Jon Snow, $c f$. Martin 1996/2011:89, discussed above on pp. 151-152. 
like a pool of blood in the torchlight. Where his other eye should have been, a thin white root grew from an empty socket, down his cheek, and into his neck' (Martin 2011/2012:206). While Bran explains that he is 'broken' and at first hopes to have his legs fixed, the Three-Eyed Crow/Raven says that this is beyond his powers, but he promises Bran: 'You will never walk again ... but you will fly' (Martin 2011/2012:207).

\section{'You died in that cave': Bran's third 'death'56}

The third time that Bran 'dies' in the Game of thrones story occurs when he accidentally draws the attention of the Night King and his army of White Walkers to the cave of the Three-Eyed Crow/Raven (GOT S06E05). Bran does this by rebelliously 'warging' on his own without the supervision of his teacher, the Crow/Raven. ${ }^{57}$ The cave comes under attack from the Army of the Dead, and in the ensuing melée, the Crow/Raven, Jojen, Bran's direwolf Summer, and Hodor are all killed. To escape, Bran time-travels and 'wargs' into Hodor's younger self in Winterfell (called Wylis in the series, but Walder in the novels), causing him to have a fit which results in his mental disability and in the fact that he can only thereafter say 'Hodor'. 'Hodor', it turns out, is a garbled version of Meera's desperate instructions to Hodor to 'hold the door' of the cave for as long as possible, so that Bran can escape (GOT S06E05).

Meera and Bran, it seems, are the only two of the party to survive. Bran is now the new Crow/Raven, the arch-greenseer, and in some ways he is utterly changed. Meera pulls him all the way back to the Wall on a sled, since Hodor is no longer there to carry him, and thereafter returns with him to Winterfell. When they reach Winterfell, Bran's emotionless reunion with the surviving members of his family reveals that he is no longer the old Bran that everyone knew (GOT S07E04). He is aloof, seemingly without feeling or human compassion. When Meera tells Bran that she is returning to her home (he actually knows this before she says anything), her mission completed, all he says to her is 'Thank you' (GOT S07E04). Meera gets emotional at his indifferent response, considering that her brother Jojen, Hodor and Summer (not to mention the Crow/Raven himself) all died for Bran's sake. Meera tells Bran: 'You died in that cave'. There has always

56 In the following section I refer to events that have taken place in the GOT series, and not in the books published to date. The series directors and writers were, however, in close consultation with George Martin in their development of these plotlines.

57 This rebellious act parallels Bran's decision to go climbing as a child which precipitates his 'fall' from the tower. 
been a suggestion, to some extent in the novels,${ }^{58}$ but more so in the television series, that Bran and Meera had 'feelings' for one another, and the audience has long been encouraged in the idea that they may well eventually become romantically involved. Thus Bran's indifferent response to her is an anticlimax for the audience, and for Meera, it seems, as well.

\section{Duality and the mantic personality}

Just as soothsaying is often ambiguous and oracles are notoriously equivocal, so the figure of the seer has been observed to be contradictory or dualistic in both western and non-western traditions. ${ }^{59}$ While Tiresias, with whom we have compared Bran, is characterized by sexual ambiguity, Bran has many contradictions. Both are disabled for looking upon what they should not, but they are also both rewarded with second sight and longevity if not immortality by way of compensation. By the seventh season of the Game of thrones series, the nature and the character of Bran himself has become highly ambiguous. By this time, Bran has symbolically 'died' three times in the tale, and has been 'reborn' at least twice. In some ways the old Bran is indeed dead, as Meera claims, but in other ways very much alive, an alert 'super-computer', as he is now a repository of universal human collective memory. ${ }^{60}$ In other ways, the old Bran is still there, underneath it all, as seen in the flair he displays, for example, when revealing to Littlefinger that he knows how he betrayed his father Eddard Stark (GOT S07E07). His omniscience puts Bran very close to the concept of a deity that is all-powerful and all-knowing, and this is not a human type of knowledge. It also raises many questions: does knowing everything before it happens, for example, mean that Bran could prevent bad things from happening?

At the same time that he has gained knowledge, wisdom, and insight in his assumption of the role of the Three-Eyed Crow/Raven, Bran has ironically ceased to develop and grow as a human being. As we have witnessed in his parting interaction with Meera Reed, in some ways the rather asexual Bran has remained a child, avoiding the development of human relationships and the usual progression

58 When Bran first meets the Reeds in A clash of kings, Meera catches him staring at her during a feast, and smiles, but Bran blushes and looks away (Martin 1998/2011:299). The theme of a potential love-interest is, as noted, much stronger in the series, but is arguably there in the novels as well. Bran's age is, however, much younger in the novels than in the series.

59 See the discussion of Teresa Carp 1983:280-284 on duality and the mantic personality.

${ }^{60}$ See the reflections of Isaac Hempstead Wright on playing Bran in the HBO production diary, discussed online by Selcke 2017. 
of life, ${ }^{61}$ after all, he is for most of the time, carried around by Hodor and later others like an infant. ${ }^{62}$ At the same time, however, in his new role as archgreenseer, the next Three-Eyed Crow/Raven, Bran is an old man, with hints of omniscience, longevity and even immortality. Bran's strange combination of physical immobility and dependence, on the one hand, and spiritual agility and omnipotence (perhaps even omnipresence), on the other, makes him simultaneously both a child and an old man. Like his alter-ego Jojen Reed, who grows smaller and more like a shrunken 'grandfather ${ }^{963}$ figure as their journey to the North proceeds, but remains infinitely wise, Bran in some ways fulfils the Jungian puer-senex archetype. ${ }^{64}$

Bran's ambiguities - whether he is alive or dead, experiencing emotions or entirely unfeeling, young or old, child or adult, human or animal, good or evil mean that he has been rendered less endearing and increasingly inscrutable to the audience. The series, particularly in season eight, seems to have deliberately encouraged speculation about whether Bran was somehow related to or was even identical with the Night King; online speculation reached a height with the start of the final season, with fans even observing that the producers had hired a new actor, who looked supposedly more like Isaac Hempstead Wright, the actor who plays

${ }^{61}$ A modern example of the ambiguous boy who refuses to 'grow up' and who remains stubbornly outside of the normal progression of human existence is, of course, J M Barrie's 'Peter Pan', a figure not without Classical precedent, as his second name 'Pan' suggests. Barrie's novel Peter Pan begins: 'All children, except one, grow up' (1911/2017:9). 'Peter Pan' has links to the puer-senex archetype discussed below. An important study of the 'Peter Pan' phenomenon is Yeoman, who remarks: 'Peter Pan remains a quality of the imagination, refusing incarnation into the normal human life cycle' (1998:63). A good parallel for 'Peter Pan' in the GOT universe is Jojen Reed, who is destined never to grow old, and who as a 'greenseer' is in some ways an alter ego for Bran. Slightly effete in contrast to his androgynous warrior sister Meera, whom Bran takes to be a boy when he first sees her (Martin 1998/2011:298), Jojen is described as being dressed head to toe in green, like the common image of 'Peter Pan', and has eyes 'the color of moss' (Martin 1998/2011:298).

$62 C f$. Martin 2011/2012:69, where Bran as 'focalizer' describes himself as 'the boy in the basket, bundled up like a babe in swaddling clothes'. In the eighth season, however, Bran is more sedately conveyed in a wooden wheelchair, a mode of transport nowadays associated with the elderly and infirm as much as with the disabled.

${ }_{63}$ See e.g. Martin 2011/2012:71.

64 Although the term puer-senex was originally used in relation to Medieval literature, Teresa Carp 1980:737-739; 1983:282-283 has shown that the theme of someone who is a seer or has special powers, and simultaneously demonstrates the traits of a boy (puer) and an old man (senex), goes well back into Classical antiquity. For the puer-senex as a Jungian concept, see Sharp 1991:109-110. 
Bran, to portray the arch-villain of the series. ${ }^{65}$ In the end, however, Bran and the Night King are shown to be linked as almost polar opposites of each other, but are not identical. In the eighth season Bran uses the fact that the Night King will always try to kill the Three-Eyed Crow/Raven, and risks his own life in order to lure and ambush the Night King. Bran thus plays a significant role in the victory of the Living over the Armies of the Dead.

In conclusion, Bran's power and authority as a seer have increased at the expense of his humanity and appeal. As a powerful, all-knowing, but aloof and unfeeling figure, Bran is no longer the little boy who was thrown from the tower. Like the pottery figurine of 'Bran' referred to in the quotation at the start of this article, which was hurled into the courtyard and smashed in order to warn the incorrigible castle-climbing boy of what would happen if he were to fall, the old Bran has been utterly destroyed and reconstructed out of the fragments. While we may not like him as much as we used to, his abilities as a seer and his nearomniscience have been a useful device in the story's development, revealing otherwise unknowable pieces of information at crucial points in the plot. While most of us would prefer to see Bran play the role of adviser and seer to King Jon Snow/Targaryen, like Merlin to King Arthur, perhaps we are misguided. Nevertheless, although Martin's series of novels is not yet complete, we can anticipate that Classical precedents will continue to play a role in the conclusion of A song of ice and fire.

\section{BIBLIOGRAPHY}

Balsley, K 2010. Between two lives: Tiresias and the law in Ovid's Metamorphoses. Dictynna 7:13-31.

Barrie, J M 1906/1911. (Pbk 2017). Peter Pan and Peter Pan in Kensington Gardens. London: Arcturus.

Carp, T 1980. Puer senex in Roman and Medieval thought. Latomus 39.3:736-739. 1983. Venus utraque: A typology of seerhood. $C W 76.5: 275-285$.

Coleman, K M 1990. Tiresias the judge: Ovid Metamorphoses 3.322-338. CQ 40.2:571-577.

Finnis, A 2019. Is Bran Stark the Night King? The Game of thrones theory explained - and why it's (almost definitely) not true. The Inewsletter, 29 April 2019, updated 6 September 2019.

${ }_{65}$ See discussion of Finnis 2019. However, for GOT Seasons 6 through 8, the Night King has been consistently portrayed by Vladimir Furdik. I thank the anonymous reviewers of Akroterion for their useful comments on this article; any remaining omissions or errors are my own fault entirely. 
https://inews.co.uk/culture/television/bran-stark-night-king-game-ofthrones-season-8-theory-spoilers-502906 (last accessed 20 Sept. 2019).

Frazer, J G 1922. The golden bough: A study in magic and religion. Old Saybrook, CT: Konecky \& Konecky.

Gilmore, M 2014. George R R Martin: The Rolling Stone interview. Rolling Stone Magazine, 23 April 2014.

https://www.rollingstone.com/culture/culture-news/george-r-r-martin-therolling-stone-interview-242487/ (last accessed 16 September 2019).

Haimson Lushkov, A 2017. You win or you die: The ancient world of Game of thrones. London, New York: I B Tauris.

Liveley, G 2003. Tiresias/Teresa: A ‘man-made-woman' in Ovid's Metamorphoses 3.318-38. Helios 30.2:147-162.

Love, D 2017. 'The face that launched 1,000 Ships' and A game of thrones: Lyanna Stark as Helen of Troy. Game of thrones and ancient history blog, article 4 (GoTAH IV), posted 3 Sept. 2017, updated 17 Sept. 2017.

The Classical Association in Northern Ireland https:/classicalassociationni.wordpress.com/2017/09/03/gotah-iv-the-facethat-launched-1000-ships-and-a-game-of-thrones-lyanna-stark-as-helen-oftroy/ (last accessed 13 November 2019).

Martin, G R R 1996. (Pbk 2011). A game of thrones: Book one of A song of ice and fire. London: Harper-Voyager.

1998. (Pbk 2011). A clash of kings: Book two of A song of ice and fire. London: Harper-Voyager.

2000. (Pbk 2011). A storm of swords: Part one: Steel and snow. Book three of $A$ song of ice and fire. London: Harper-Voyager.

2011. (Pbk 2012). A dance with dragons: Part one: Dreams and dust. Book five of A song of ice and fire. London: Harper-Voyager.

2011(b). (Pbk 2012). A dance with dragons: Part two: After the feast. Book five of $A$ song of ice and fire. London: Harper-Voyager.

Miller, M 2019. Game of thrones' big finale twist is exactly what George R R Martin has planned for his books. Esquire, 31 May 2019.

https://www.esquire.com/entertainment/tv/a27677422/game-of-thronesgeorge-rr-martin-book-vs-show-ending-differences (last accessed 20 September 2019).

Selcke, D 2017. Is the old Bran Stark really dead? Isaac Hempstead Wright weighs in.

https://winteriscoming.net/2017/08/09/isaac-hempstead-wright-interviewbran-stark-three-eyed-raven-died-cave (last accessed 9 September 2019).

Sharp, D 1991. Jung lexicon: A primer of terms and concepts. Toronto: Inner City Books. 
Sider, D 1996. As is the generation of leaves in Homer, Simonides, Horace, and Stobaios. Arethusa 29.2:263-282.

Tolkien, J R R 1954. (Pbk 1993). The lord of the rings. London: Harper Collins.

Yeoman, A 1998. Now or neverland: Peter Pan and the myth of eternal youth: A psychological perspective. Toronto: Inner City Books. 